\title{
Development and preservation of tourist resources: example of the Seto Inland Sea in Japan
}

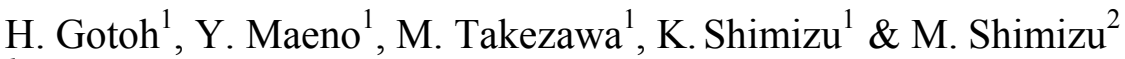 \\ ${ }^{1}$ Nihon University, Tokyo, Japan \\ ${ }^{2}$ Tekken Corporation, Japan
}

\begin{abstract}
Japan has a total of 29 national parks, 55 quasi-national parks, and numerous environmental preservation areas. The Seto Inland Sea National Park consists of the ocean area separating Honshu, Shikoku, and Kyushu; three of the main islands of Japan. It serves as an international waterway, connecting the Pacific Ocean to the Sea of Japan and Osaka Bay, and it provides a sea transport link to the industrial centers of the Kansai region, including Osaka and Kobe. Before the construction of the Sanyo Main Railroad Line, it was the main transportation link between Kansai and Kyushu. The Inland Sea region is known for its moderate climate, stable year-round temperatures, and relatively low levels of rainfall. Since the 1980s, its northern and southern shores have been connected by the three routes of the Honshu-Shikoku Bridge Project, including the Great Seto Bridge, which serves both railroad and automobile traffic. The Inland Sea measures $450 \mathrm{~km}$ from east to west, and 15 to $55 \mathrm{~km}$ from north to south. In most places, the Seto Inland Sea is relatively shallow and the average depth is $37.3 \mathrm{~m}$; the deepest point is $105 \mathrm{~m}$. There are approximately 3,000 islands located in the Seto Inland Sea, including the larger islands Awajishima and Shodoshima. Many of the smaller islands are uninhabited. In this paper, the present state and future potential of some of these islands are examined and proposed within the context of tourism in Seto Inland Sea.
\end{abstract}

Keywords: Seto Inland Sea, Honshu-Shikoku Bridge Project, National Park. 


\section{Introduction}

The "tourist resource" is a factor used by the tourism industry that attempts to quantify the demand for enjoying leisure activities, such as shopping and sightseeing, and promoting the community. Japan's main tourist resources are sightseeing, places of scenic beauty, special historical attractions, recreational facilities, and regional specialties reflective of Japan's traditional culture, such as cuisine and local festivals. Currently, tourism in Japan has a vibrant domestic sector and eight million foreign visitors each year. However, steady urbanization has been ongoing in Japan since the 1960s. The mass migration to cities has caused the depopulation of rural areas and resulted in a substantially serious decrease of jobs, aging, and home-based industries. These changes have had an especially adverse effect on the size of the labor force in mountain, farming and fishing villages, as well as community services and support networks. Practitioners of more traditional and cultural activities, e.g., handicrafts, and participants in local festivals or dancing performances have also felt these effects. To resolve these problems and others caused by urbanization, e.g., traffic and pollution, it is necessary to rebuild the economy and boost the population of rural areas. In order to address these issues, the "Tourism Nation Promotion Plan" was adopted by the Japanese Cabinet on June 29th, 2007 [1]. It sets out basic principles related to national tourism and includes a number of government measures and other actions aimed at specific targets, as well as what is necessary to achieve them. These targets include 1) increasing the number of foreign travelers to Japan to 10 million, 2) increasing the number of Japanese tourists traveling overseas to 20 million, 3 ) increasing the value of tourism consumption to 30 trillion yen, 4) increasing the number of overnight stays per person in connection with domestic travel to 4 nights per year, and 5) increasing the number of international conferences held in Japan by at least $50 \%$. Based on this plan, the government will make concerted efforts to implement measures in a comprehensive and systematic manner as a means to further promote Japan as a tourism nation, and ensure that tourism remains a vital part of the Japanese economy and society in the years to come.

\section{Seto Inland Sea}

The Seto Inland Sea is surrounded by the coastlines of Yamaguchi, Hiroshima, Okayama, Hyōgo, Kagawa, Ehime, Fukuoka, and Oita Prefectures on the major islands of Honshu, Shikoku and Kyushu in Japan. This region is known for having a moderate climate with stable year-round temperatures and relatively low levels of rainfall. It is often referred to as "the land of fair weather." The Seto Inland Sea is also famous for its periodic red tides, caused by dense groupings of certain phytoplankton that result in the death of large numbers of fish [2]. Since the 1980s, the northern and southern shores of the region have been connected by the three routes of the Honshu-Shikoku Bridge Project [3, 4], including the Great Seto Bridge, which serves both rail and motor vehicle traffic. The Seto Inland Sea is $450 \mathrm{~km}$ long from east to west and the width from south 
to north varies between 15 and $55 \mathrm{~km}$. In most places, the water depth is relatively shallow, with an average depth of $37.3 \mathrm{~m}$ and a maximum of $105 \mathrm{~m}$. The Naruto Strait connects the eastern part of the Seto Inland Sea to the Kii Channel, which in turn connects to the Pacific Ocean. The western part of the Seto Inland Sea connects to the Sea of Japan through the Kanmon Straits and to the Pacific through the Bungo Channel. There are also many straits located between the major islands, as well as a number of smaller ones that pass between islands or connect the Seto Inland Sea to other seas or the Pacific. Almost 3,000 islands are located in the Seto Inland Sea, including the larger islands of Awajishima and Shodoshima. Many of the smaller islands are uninhabited. The coastal area of the Seto Inland Sea is one of the most industrialized sections of modern Japan. Major industrial cities in Honshu, in addition to Osaka, Kobe, and Hiroshima, are Kurashiki, Kure, Fukuyama, and Ube, as well as Sakaide, Niihama, and Imabari in Shikoku. Innoshima is also known for its ship factory. The main industries are steel production, ship construction, and since the 1960s, oil refining and oil-derived production. Thanks to a moderate climate and beautiful landscape, fishing, agriculture, and tourism bring a substantial amount of income to the area as well. Today, the Seto Inland Sea serves mainly as a local transportation route between coastal areas and islands on the sea as well as a major transportation route for international and domestic cargo. The area's major ports are Kobe, Okayama, Takamatsu, Tokushima, Matsuyama, and Hiroshima. Honshu and Shikoku have been connected by three series of bridges since the late 1980s. Those series of bridges, collectively known as the Honshu-Shikoku Bridge Project, are, from east to west, Kobe-Awaji-Naruto Route, KojimaSakaide Route, and Onomichi-Imabari Route. On the other hand, no bridge over the Seto Inland Sea connects Kyushu to another island. Historically, the Seto Inland Sea has served four coastal areas as a transport line: the Kansai area of Osaka-Hyogo-Wakayama Prefectures, the Chugoku area of OkayamaHiroshima-Yamaguchi Prefectures, the Shikoku area of Kagawa-Ehime Prefectures, and the eastern Kyushu area of Fukuoka-Oita Prefectures. The Seto Inland Sea provides each of these areas with local transportation and connects each to the others, as well as areas even further, including the coastal area of the Sea of Japan, Korea, and China. After Kobe port was founded in 1868 to serve foreign ships, the Seto Inland Sea became a major international waterway with connection to the Pacific. Due to the development of land transportation, the travel between east and west, i.e., transportation within Shikoku Island, within Honshu Island, and between Honshu Island and Kyushu Island, shifted to railroad and road transport. Two railways, Sanyo Main Line in Honshu Island and Yosan Main Line in Shikoku, were built. Those railway lines stimulated the local economy. Many short railroads were planned to connect certain stations of those two lines and a local seaport on the Seto Inland Sea, and some of them were actually built. Some train ferry lines ran between Honshu and Shikoku before, but the ferry line was abolished when the Kojima-Sakaide Route was finished and began serving both coastal areas. Over 700 large and small islands with intricate shorelines form the beautiful, distinct scenery of the Seto Inland Sea. The climate is temperate with little rainfall, yet 664 different water sources 
feed into the Sea from its surrounding mountains. On average, 50 billion cubic meters of water flow into the Sea from these sources every year [5]. Figure 1 shows a map of Seto Inland Sea.

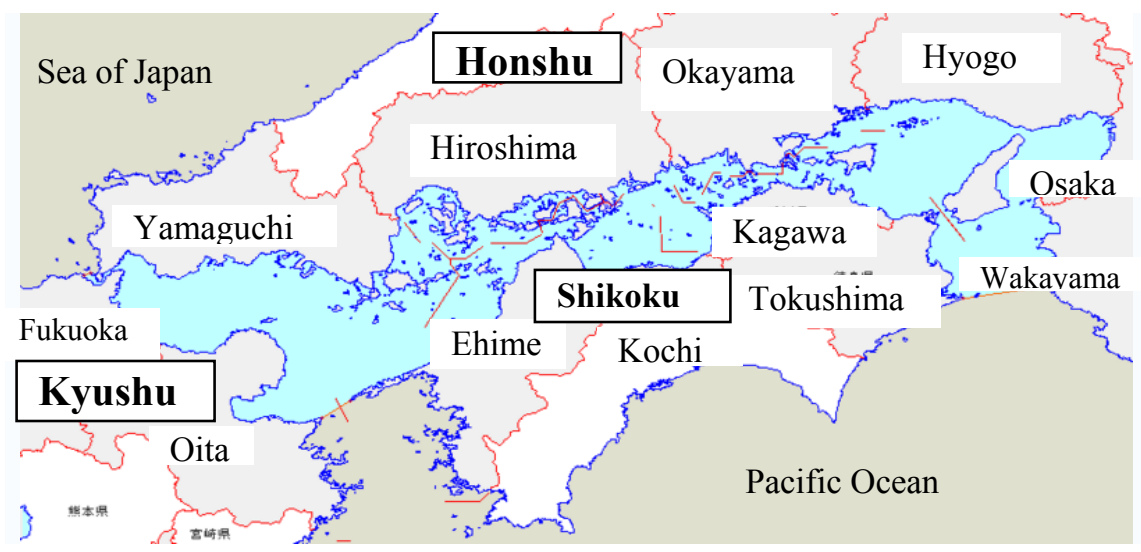

Figure 1: Map of Seto Inland Sea (from Wikipedia: the free encyclopedia).

\section{Islands subject to questionnaire and hearing}

The Kojima-Sakaide and the Onomichi-Imabari Routes are shown in Figures 2 and 3 [3], respectively. From 2005 to 2009, inhabitants who had lived on the islands that are crossed by the Kojima-Sakaide Route, Hitsuishijima Island, Iwakurojima Island and Yoshima Island, for 8 years or more were sent questionnaires about future development. The Kojima-Sakaide Route is both a highway on the Seto-Chuo Expressway and a railway on the Japan Railway Seto-Ohashi Line. The total length of the highway and railway are about $39 \mathrm{~km}$ and $32 \mathrm{~km}$, respectively. Outlines of each island crossed by the Kojima-Sakaide Route in 2005 are shown in Table 1 [4, 6]. Hitsuishijima Island is under Sakaide City in Kagawa Prefecture. The site of Hitsuishijima Island is located at the $12 \mathrm{~km}$ marker crossing the Seto Ohashi Bridge to the north of the Sakaide-Kita IC in Kagawa Prefecture. The main industry is shellfish trawling. A single-span stiffening truss suspension bridge with cantilever spans $(230 m+940 m+230 m)$

Table 1: $\quad$ Outline of each island crossed on the Kojima-Sakaide route.

\begin{tabular}{|l|l|l|l|l|l|l|}
\hline & $\begin{array}{c}\text { Area } \\
\left(\mathrm{km}^{2}\right)\end{array}$ & $\begin{array}{c}\text { Length } \\
\text { of } \\
\text { coastline } \\
(\mathrm{km})\end{array}$ & $\begin{array}{c}\text { Number of } \\
\text { households }\end{array}$ & $\begin{array}{c}\text { Population } \\
\text { (persons) }\end{array}$ & $\begin{array}{c}\text { Population } \\
\text { density } \\
\left(\text { persons } / \mathrm{km}^{2}\right)\end{array}$ & $\begin{array}{c}\text { Max. } \\
\text { sea level } \\
(\mathrm{m})\end{array}$ \\
\hline 1 & 0.85 & 5.4 & 97 & 236 & 277 & 79 \\
\hline 2 & 0.16 & 1.7 & 32 & 94 & 587 & 28 \\
\hline 3 & 1.10 & 4.3 & 73 & 142 & 129 & 74 \\
\hline
\end{tabular}

1. Hitsuishijima Island 2. Iwakurojima Island 3. Yoshima Island. 
links Honshu with Hitsuishijima Island. Another bridge which links Hitsuishijima Island to Iwakurojima Island is an identical cable-styled bridge with $420 \mathrm{~m}$ of center span and considered to be more aesthetically suitable for the Seto Inland Sea. Iwakurojima Island is located at the $10.2 \mathrm{~km}$ marker north of Sakaide-Kita IC. The main industry of Iwakurojima Island is inshore chum salmon gillnet fishing. A two-span continuous steel truss girder bridge $(125 \mathrm{~m}+137 \mathrm{~m})$ and a three-span continuous steel truss girder bridge $(146 \mathrm{~m}+$ $215 \mathrm{~m}+135 \mathrm{~m}$ ) link Iwakurojima Island to Yoshima Island. These bridges were chosen again mainly due to aesthetic reasons because the height of the main truss makes a smooth outline with an adjacent identical cable-style bridge. Sakaide City in Kagawa Prefecture is located on Yoshima Island. Yoshima Island is located at the $8.2 \mathrm{~km}$ marker just to the north of Sakaide-Kita IC. The main industries have historically been granite quarries and salt pans. There are restaurants, snack bars, free rest stations, temporary sleeping rooms, lookout points, food stands, and various other amenities in parking areas, as well as a special ocean-related products counter in a tourist facility on the fisherman's wharf. Yoshima Island links Sakaide-Kita IC to Shikoku Island with three-span continuous stiffening truss girder suspension bridges of $900 \mathrm{~m}$ and $1100 \mathrm{~m}$ long to permit trains to travel safely.

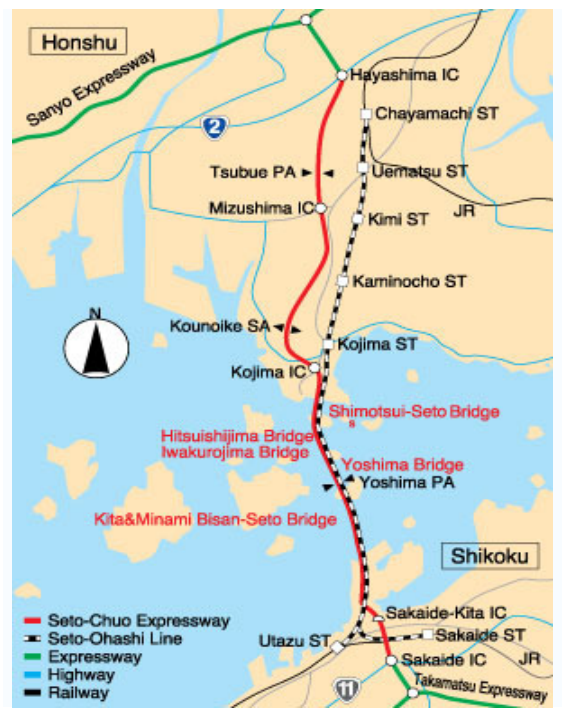

Figure 2: Kojima-Sakaide Route.

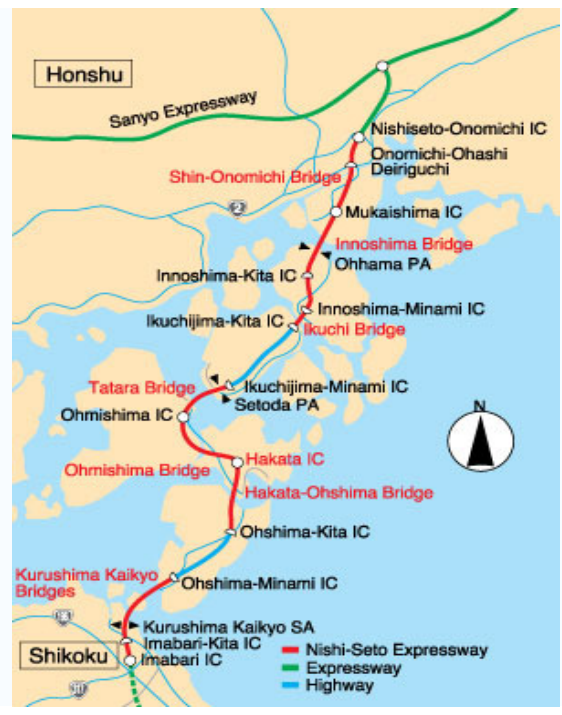

Figure 3: Onomichi-Imabari Route (From Honshu-Shikoku Bridge Express Company Limited [3]).

Located on the Onomichi-Imabari Route, the Nishi-Seto Expressway, also known as Shimanami Kaido, is a $60 \mathrm{~km}$ long toll road that passes through a series of bridges and islands from Onomichi City in Hiroshima Prefecture on 
Honshu to Imabari City in Ehime Prefecture on Shikoku, as shown in Figure 3. Table 2 is an outline of each island crossed on the Onomichi-Sakaide Route in $2005[4,6]$. The total cycling distance is $70 \mathrm{~km}$ including the bridge access ramps. This route consists of nine long span bridges and connects the six islands of Mukaishima, Innoshima, Ikuchijima, Ohmishima, Hakatajima and Ohshima. Mukaishima Island is the administrative district of Onomichi City in Hiroshima Prefecture. The main industry of the island is agriculture, and it has 670 farmhouses and more than 51 fisheries.

Table 2: $\quad$ Outline of each island crossed on the Onomichi-Imabari route.

\begin{tabular}{|c|c|l|l|l|l|l|}
\hline & $\begin{array}{c}\text { Area } \\
\left(\mathrm{km}^{2}\right)\end{array}$ & $\begin{array}{c}\text { Length } \\
\text { of } \\
\text { coastline } \\
(\mathrm{km})\end{array}$ & $\begin{array}{c}\text { Number } \\
\text { of } \\
\text { households }\end{array}$ & $\begin{array}{c}\text { Population } \\
\text { (persons) }\end{array}$ & $\begin{array}{c}\text { Population } \\
\text { density } \\
\left.\text { (persons/km }{ }^{2}\right)\end{array}$ & $\begin{array}{c}\text { Max. } \\
\text { sea } \\
\text { level } \\
(\mathrm{m})\end{array}$ \\
\hline 1 & 22.22 & 20 & 10307 & 26429 & 1189.4 & 283 \\
\hline 2 & 39.76 & 32 & 11728 & 26130 & 692.4 & 408 \\
\hline 3 & 33.74 & 33.6 & 3834 & 9032 & 301.0 & 472 \\
\hline 4 & 64.54 & 88.8 & 3471 & 7720 & 132.3 & 437 \\
\hline 5 & 20.86 & 53.5 & 3056 & 7795 & 303.6 & 304 \\
\hline 6 & 41.87 & 49.9 & 3249 & 8279 & 197.7 & 381 \\
\hline
\end{tabular}

1. Mukaishima Island; 2. Innoshima Island; 3. Ikuchijima Island; 4. Ohmishima Island; 5. Hakatajima Island; 6. Ohshima Island.

The northern district of Mukaishima Island is a residential area containing large numbers of residents who commute to their offices across the channel in Onomichi City. Mukaishima Island is linked to Onomichi City by two cablestayed bridges. One was built in 1968 and the other, having a five span continuous box girder and a total length of $546 \mathrm{~m}(80.5 \mathrm{~m}+80.8 \mathrm{~m}+85.0 \mathrm{~m}+$ $215.0 \mathrm{~m}+85.0 \mathrm{~m}$ ), was constructed in 1999. The new bridge was constructed 55 $\mathrm{m}$ west of and parallel to the old bridge. Great care was taken to ensure that the new bridge would harmonize with the older bridge and its surrounding scenery and not disrupt the existing aerodynamic stability. The length of the suspension bridge connecting Mukaishima Island to Innoshima Island is $1,270 \mathrm{~m}(250 \mathrm{~m}+$ $770 \mathrm{~m}+250 \mathrm{~m}$ ) and has a high clearance of $50 \mathrm{~m}$ for ships. All these attributes make this bridge appear slender. This bridge sometimes enjoys a reputation as being the most beautiful suspension bridge in Japan. The main tourist facilities of Mukaishima Island are an orchid center introduced to Japan from the west, a marine youth center, and Takami mountain of Muro-Akame-Aoyama Quasi National Park. The administrative district of Innoshima Island is Onomichi City. The bridge connecting Innoshima Island with Ikuchijima Island is a cable-stayed bridge with a center span of $490 \mathrm{~m}$ and a total length of $790 \mathrm{~m}$. The major industries of Innoshima Island are citrus farming and shipbuilding. There are numerous mountains that lie between $95.5-408.1 \mathrm{~m}$ above sea level and various places of scenic beauty or historic interest. Ikuchijima Island is also the administrative district of Onomichi City. Sightseeing spots are Kosanji Temple, 
which houses 19 important cultural properties, an art museum and a sunset beach. Oranges and lemons are the specialties of the island. Ikuchijima Island and Omishima Island are connected by a cable-stayed bridge built in 1999 with a center span of $890 \mathrm{~m}$ and a total length of $1480 \mathrm{~m}(270 \mathrm{~m}+890 \mathrm{~m}+320 \mathrm{~m})$. Omishima Island is the administrative district of Imabari City in Ehime Prefecture. It is designated as a national treasure and an island of the Gods. The main industry is agriculture, and there are also some shipbuilding yards, sewing factories and salt works. The Shinto shrine is the top tourist attraction on the island. Recently, tourism campaigns have focused on green-tourism, training camps, and school excursions. Omishima Island and Hakatajima Island are connected by a single span two-hinged half-through solid rib arch bridge with side ties. The main industries of Hakatajima Island are citrus and flowering plant growing, prawn farming, shipbuilding, salt works, sewing, and shipping. Hakatajima Island and Ohshima Island are connected by two bridges. One is built with a three span continuous steel box girder $(90 \mathrm{~m}+145 \mathrm{~m}+90 \mathrm{~m})$ with an orthotropic steel bridge deck, and the other is a single span two-hinged stiffening box girder suspension bridge (length $560 \mathrm{~m}$ ). Hakatajima Island and Ohshima Island are governed by Imabari City in Ehime Prefecture. The main industry of Ohshima is citrus farming, marine products, shipbuilding, rock quarries, and sewing. There are two lookout points for the straits and bridge at Ohshima Island. Ohshima Island and Imabari City of Shikoku Island are connected by a 4-km-long straight bridge which consists of three suspension bridges. The spans of the first bridge are $50 \mathrm{~m}, 140 \mathrm{~m}, 600 \mathrm{~m}$, and $170 \mathrm{~m}$, for a total length of $960 \mathrm{~m}$; the spans of the second bridge are $250 \mathrm{~m}, 1020 \mathrm{~m}, 245 \mathrm{~m}$, for a total length of $1515 \mathrm{~m}$; and the spans of the third bridge are $260 \mathrm{~m}, 1030 \mathrm{~m}$, and $280 \mathrm{~m}$, for a total length of $1570 \mathrm{~m}$. All three suspension bridges are structurally asymmetric and cross over two channels of an international shipping route.

In 2007 and 2010, two surveys were conducted concurrently concerning the Kobe-Awaji-Naruto Expressway Route, connecting Kobe City of Honshu and Naruto City of Shikoku via Awaji Island (Figure 4), and Shodoshima Island, the largest island not connected to Honshu and Shikoku (Figure 5). This is the shortest route between the economically active Kobe-Osaka area of Honshu and many parts of Shikoku, and is expected to bring about a great effect on the local economy. The Akashi -Kaikyo Bridge, also known as the Pearl Bridge, connects Kobe and Iwaya on Awaji Island in Hyogo Prefecture. It has the longest central span of any suspension bridge in Japan, with a center span 1,991 m long and a total length of $3910 \mathrm{~m}$. It was designed with a two-hinged stiffening girder system and the two main supporting towers rise $298 \mathrm{~m}$ above sea level. Two parks in proximity of this bridge have been built for tourists. This bridge is also illuminated by lighting displays, which vary according to the seasons and time of day. Awaji Island is an island in Hyogo Prefecture in the eastern part of the Seto Inland Sea between the islands of Honshu and Shikoku. Awaji Island has an area of $592.17 \mathrm{~km}^{2}$, roughly $200 \mathrm{~km}$ of coastline, about 58,000 households, and a population of around 150,000 people. The population of Awaji Island decreased 


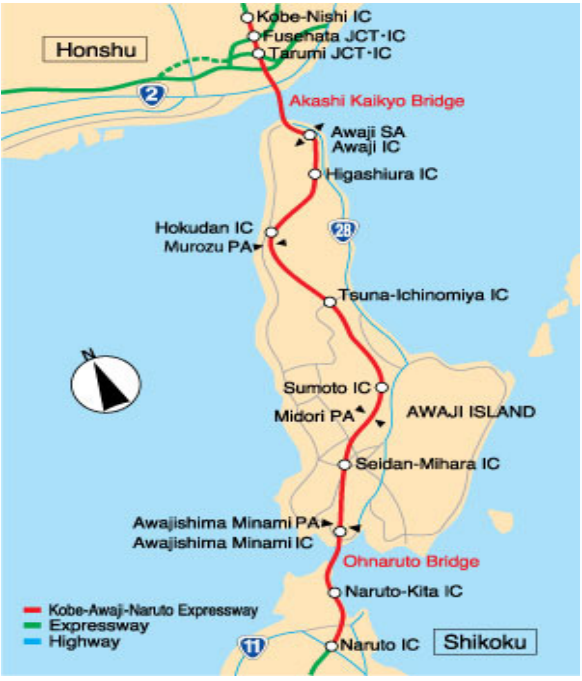

Figure 4: Kobe-Awaji-Naruto Route.

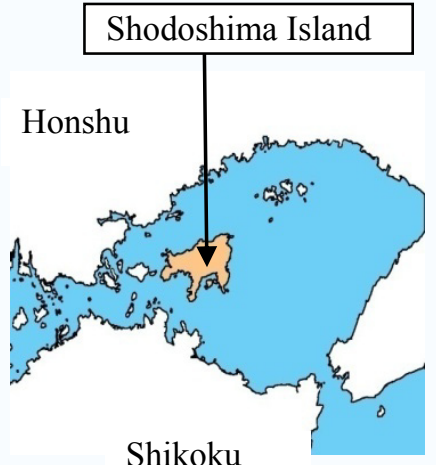

Figure 5: Shodoshima Island.

by about 5\% between 2000 and 2010. According to 2010 statistics, people 15 years of age or younger make up about $12 \%$ of the population, adults between 15-65 years make up 58\%, and adults 65 years or older make up 30\%. As a way of transit between Honshu and Shikoku, Awaji originally meant "the road to Awa", the historic province bordering the Shikoku side of the Naruto Strait, and now part of Tokushima Prefecture.

There are four mountainous regions $(522 \mathrm{~m}, 448 \mathrm{~m}, 608 \mathrm{~m}$ and $569 \mathrm{~m}$ above sea level) from the northeast to the southeast of Awaji Island. The Awaji Ningyou-joururi, an over 500-year-old form of traditional puppet theater, performs several shows daily in the Awaji Ningyou-joururi Hall on the southern part of Awaji Island. This hall is designated part of the intangible cultural heritage of Japan. The Awaji puppets currently perform popular traditional dramas, but have their origins in religious rituals. The Onaruto Bridge connecting Awaji Island and Shikoku Island spans across Naruto Strait, which is famous for tidal whirlpools. These recurring whirlpools, known as the Naruto whirlpools, are commonly located below the bridge. They are caused by tidal currents passing over undersea ridges and causing very strong eddy currents between the Seto Inland Sea and the Pacific Ocean, some of which make large, deep whirlpools. This bridge has a tourist attraction built into the south side anchor, the Uzunomichi Walkway, an enclosed walkway that extends to the south tower to allow visitors to view the whirlpools, best seen during low tide, through side and floor windows. Tourist boats and other vessels routinely circle the towers, allowing visitors to actually see the depth of the whirlpools up close. The view from the bridge observatory lets visitors see the pattern created by the eddy currents extending out for quite a distance. The total length of this bridge is about $1630 \mathrm{~m}$ with a center span of $876 \mathrm{~m}$. For tourism, three cities on Awaji 
Island promote the idea of making longer stays of 2 or 3 days in order to grasp the more fascinating aspects of the Island.

Next, we surveyed Shodoshima, the largest island in the Seto Inland Sea not connected with Honshu and Shikoku (Figure 5). It is a popular destination for domestic tourism in Japan, and the first area of Japan to successfully grow olives. It is therefore sometimes known as "Olive Island." It is part of Kagawa Prefecture and has an area of $153.30 \mathrm{~km}^{2}$ with a coastline of $126 \mathrm{~km}$. There were about 13,400 families and 31,500 persons living on this island in 2010. The Dobuchi Strait, the narrowest strait $(9.93 \mathrm{~m})$ in the world, and Hoshikajou Mountain (817 $\mathrm{m}$ above sea level), a wonderful vantage point for taking pictures of the Kojima-Sakaide and Kobe-Awaji-Naruto Routes, are located here. The population of Shodoshima Island declined by a rate of $20 \%$ between 2000 and 2010 due to population transfer to Honshu and Shikoku. In 2010, young people 15 years of age or younger made up about $10 \%$ of the population, adults between 15 and 55 made up about 55\%, and adults 65 years and older made up about $35 \%$. The tourist society of Shodoshima has recently been planning the Shodoshima life of an olive.

\section{Considerations}

Results of the questionnaire sent to inhabitants of islands through the KojimaSakaide, Onomichi-Imabari, and Akashi-Awaji-Naruto Routes revealed that the majority of respondents $(80 \%$ or more) thought it would be very convenient to travel to cities and towns in Honshu and Shikoku if roads connecting the 3 express highways between Honshu and Shikoku were built. However, a majority of residents ( $80 \%$ or more) also responded that highway tolls would be too expensive to make it worth the savings in time. Results of the questionnaire for tourists who visited the Seto Inland Sea area showed that a majority of tourists ( $80 \%$ or more) thought each bridge went well with the surrounding panorama. About half of the inhabitants living on each island answered that even though tourist traffic was increasing, the number of tourists staying on each island was decreasing. Many inhabitants expect an increase in visitors and businesses to come from Honshu to each island of the Seto Inland Sea if more bridges are built between Honshu and Shikoku. Ironically, many businesses have left each island to accommodate office workers making business trips since the completion of bridges between Honshu and Shikoku. A majority of visitors ( $80 \%$ or more) responded that all of the modern long-spanned bridges in the Seto Inland Sea agree with each regional landscape. They also largely agreed that there were plentiful traditional performing arts, historical monuments, distinct museums, and delicious foods on each island of the area. Half of the inhabitants of each island answered that they were satisfied to live on their islands and hope to settle there permanently. However, $60 \%$ or more of inhabitants have neither children at home nor children away that are planning on returning to succeed them. Most inhabitants $(80 \%$ or more) answered that welfare, medical services and educational facilities, aside from those on Honshu and Shikoku, were insufficient, even though their quality of life on each island was better than it had 
been in the past. Even more inhabitants (85\% or more) on each island answered that their natural environment and human relations were very good, and that they hope to reconstruct an island vibrant with life through job opportunities from tourism, citrus markets, and marine and agricultural products. About 40 million tourists visited the Seto Inland Sea National Park in 2007. The Setouchi Shimanami Kaido 3-Day March, a 3-day festival which takes place along the Onomichi-Imabari Route, draws the most visitors of any festival in Western Japan. Multiple liners and ferry boats connect Honshu with each island or Shikoku, but the number of tourists boarding liners and boats is decreasing every year. Many inhabitants also reported that many young people plan on leaving the islands if the quiet lifestyle there fails to change. Even though these islands have an abundance of tourist resources such as diverse flora, beautiful shorelines, a quiet and clean sea, abundant citrus fruits, fresh fish, and hospitable locals, the Japanese Government needs to invest more in these blessed places if Japan truly seeks new developments in tourism policy.

\section{Conclusions}

The Seto Inland Sea is the largest enclosed coastal sea in Japan and is located at the approximate center of the islands constituting the nation's territory. It covers an area of $23,000 \mathrm{~km}^{2}$ and has a coastline that stretches for a total length of 6,900 $\mathrm{km}$. It is a shallow sea with an average depth of $38 \mathrm{~m}$ that can hold 880 billion $\mathrm{m}^{3}$ of water. Seven hundred islands of varying size with intricate shorelines form the beautiful and distinct scenery of this region. The climate is moderate (the average annual temperature is $15^{\circ} \mathrm{C}$ ) with little rainfall (the average annual rainfall is $1,000-1,600 \mathrm{~mm}$ ), and it is fed by 664 different water sources from its surrounding mountains. On average, 50 billion $\mathrm{m}^{3}$ of water flow into the sea from these sources every year. The coastal regions bordering the Seto Inland Sea are home to about 30 million people, $24 \%$ of the entire population of Japan (about 130 million). The island population was about 440,000 in 2010. The most populated island in the sea is Awajishima Island, with about 150,000 inhabitants, followed by Shodoshima Island, with about 35,000. The areas of Awajishima and Shodoshima Islands are about $592 \mathrm{~km}^{2}$ and $153 \mathrm{~km}^{2}$, respectively. From ancient times, the Seto Inland Sea has played a leading role in maritime transport. Numerous cargo vessels can be seen at any given time passing to and fro through this narrow sea. However, in the 1980s, its northern and southern shores were connected by the three routes of the Honshu-Shikoku Bridge, including the Great Seto Bridge, which serves both rail and motor vehicle traffic. Thereafter, cargo vessel traffic began to gradually decrease. The Seto Inland Sea is a major fishing area. Over 500 marine species are known to live in the Seto Inland Sea. The coastal area is one of the most famous tourist destinations in Japan. It was designated Setonaikai National Park in 1934. Various projects that aim to promote environmental awareness and conservation of the Seto Inland Sea are advanced by the Association for the Environmental Conservation of the Seto Inland Sea [5]. The Seto Inland Sea Road Project [7] is a project initiated by Hiroshima Prefecture with the purpose of researching and making connections 
between the islands scattered throughout the sea and the regional resources that are available to them. The coordination across prefectural boundaries is paramount, as the opinions of inhabitants living in the Seto Inland Sea and neighboring areas are important for restoring the economies of the islands. The following conclusions were drawn from the questionnaires and correspondence of inhabitants living on the islands:

1) Although hard infrastructure, such as water and sewage works, roads, and harbors, exist on many of the islands, soft infrastructure, such as welfare services, medical services, and educational facilities, are underdeveloped.

2) Tourist resources need to be developed in the center of the three routes connecting Honshu and Shikoku Islands. However, aspects related to the preservation of the natural environment of the islands also need to be considered.

3) Employment opportunities for the youth need to be created by the tourist industry of the Seto Inland Sea.

4) Since the completion of the Honshu-Shikoku Bridge, it has been very convenient for inhabitants of the islands to live so close to Honshu and Shikoku, but a large number of the island inhabitants feel as though there has been a decline in employment, the environment, and the and the tourism industry recently.

\section{References}

[1] Japan Tourism Agency, Tourism Nation Promotion Basic Plan, http://www.mlit.go.jp/kankocho/en/vision/plan.html, 2012.

[2] Wikipedia, The free Encyclopedia, Inland Sea, http://en.wikipedia.org /wiki/Inland-Sea, 2012.

[3] Honshu-Shikoku Bridge Express Company Limited, Information, http://www.jb-honshi.co.jp/english/information/information-d.html, 2012.

[4] Bridge and Offshore Engineering Association, The Honshu-Shikoku Bridge, 1999.

[5] Association for the Environmental Conservation of the Seto Inland Sea, The Seto Inland Sea - A Profile of Nature's Kaleidoscope, http://www.seto.or.jp /setokyo/eng/e-toppage/e-top-main.htm, 2012.

[6] Japanese Solitary Island Center: An annual statistical report of solitary islands in Japan, 2012.

[7] H. Kamei, Sea Road Design of Seto Inland Sea, http://dic.yahoo.co.jp/newword?ref=1\$index=201000207\&category=4,2012. 